\title{
Phenolic compounds and radical scavenging potential of twenty Cameroonian spices
}

\author{
Abdou Bouba $\mathrm{A}^{1^{*}}$. Njintang $\mathrm{Y} . \mathrm{N}^{2}$ Scher $\mathrm{J}^{3}$ and Mbofung $C \mathrm{M} \mathrm{F}^{1}$ \\ ${ }^{1}$ Department of Food Science and Nutrition, ENSAI, University of Ngaoundere, \\ PO Box 455 Ngaoundere, Cameroon \\ 2 Department of Biological Sciences, Faculty of Sciences, University of Ngaoundere, \\ PO Box 454 Ngaoundere, Cameroon \\ ${ }^{3}$ Laboratoire de Science et Génie Alimentaires (LSGA), Nancy-University, 2 avenue de la \\ Forêt de Haye B.P. 172 F-54505 Vandœuvre-lès-Nancy \\ * To whom correspondence and reprint requests should be addressed: \\ Tel 00 (237) 79195 02, Email: abdouarmand@yahoo.fr \\ ABSTRACT
}

\begin{abstract}
The antioxidant activity and phenolic content of twenty different spices commonly used in Cameroon were analyzed with the view of updating our present knowledge on their nutritional and nutraceutical potentials. To achieve this aim, the ferric iron reducing activity (FIRA), hydroxyl radical scavenging activity (HRSA), free radical scavenging activity (FRSA), total phenols, flavonoids, proanthocyanidins, and tannins content were analyzed using current techniques. In all the cases significant variations $(p<0.001)$ were observed in the levels of the parameters analyzed. The different parameters varied as follows: total phenols $(1.05-38.80 \mathrm{~g} / 100 \mathrm{~g})$, flavonoids $(0.00 \mathrm{~g}-5.94 \mathrm{~g} / 100 \mathrm{~g})$, tannins $(0.00-281.5 \mathrm{mg} / 100 \mathrm{~g})$, FIRA $(1.55-168.63 \mathrm{mg} / 100$ g), FRSA (3.96 - $71.5 \mathrm{mg} / \mathrm{g})$, HRSA (0.01 - $2.45 \mathrm{mg} / 100 \mathrm{~g})$. Using Principal Component Analysis (PCA), $79 \%$ of the variation in spices was found to be mainly associated with their FRSA, FIRA, total phenols, flavonoids, and proanthocyanidins content. Furthermore, using K-means classification, it was possible to classify the spices into four major groups, each of relatively similar composition as follows: Group 1 has high FRSA and FIRA levels, high phenols, and flavonoids contents: Dichrostachys glomerata, Fagara leprieuri; Group 2 has high HRSA levels: Fagara xanthoxyloïdes, Mondia whitei, Pentadiplandra brazzeana, Piper guineense, Scorodophleus zenkeri (fruit), Scorodophleus zenkeri (bark); Group 3 has low levels in all variables: Aframomum daniellii, Hua gabonii (fruit), Monodora myristica, Dorstenia psilurus, Hua gabonii (bark), Piper umbellatum, Solanum melongena, Scleria striatinux, Xylopia aethiopica and Group 4 has moderate levels of FRSA and FIRA, phenols, flavonoids and proanthocyanidins: Echinops giganteus and Tetrapleura tetraptera. In addition Pearson correlation analysis revealed strong positive correlations between FRSA and FIRA (93\%), between FRSA and total phenols $(90 \%)$ and between flavonoids and total phenols (93 \%). Dichrostachys glomerata and Fagara leprieuri were the spices with the best antioxidant activity and highest phenolic content.
\end{abstract}

Keywords: Spices, antioxidant activity, phenolic compounds, PCA, K-means classification

\section{INTRODUCTION}

Free radicals produced by radiation, chemical reactions and several redox reactions of various compounds in living tissues and cells contribute to protein oxidation, DNA damage, and lipid peroxidation (Halliwell, 1996; Morrissey and O'Brien, 1998). These oxidative stresses are common in such chronic health disorders as cancer, atherosclerosis, diabetes and liver cirrhosis (Muramatsu, Kogawa, Tanaka, Okumura, Koike, Kuga et al., 1995; Steinberg, Parthasarathy, Carew, Khoo, \& Witztum,
1989). Generally protection against the toxicity of these free radicals is provided by antioxidant defences including polyphenols, enzymes (e.g. glutathion peroxidase, catalase and superoxide dismutase), proteins (e.g. ferritin), vitamins (A, C, E) and trace elements (e.g. selenium, zinc). Under a normal physiological state, research evidences point to the fact that these antioxidants have the capacity to perfectly regulate the production of reactive oxygen species (ROS). It is in this connection that several studies have shown that foods of high 
antioxidant activity tend to improve health of the consumers by acting as free radical scavengers or reductors (Rice-Evan, Miller, \& Paganga, 1996; Zheng \& Wang, 2001) and such reduce the risk of chronic diseases (Velioglu, Mazza, Gao, \& Oomah, 1998; Liu \& Ng, 2000; Sweeney, Kalt, Mackinnon, Ashby, \& Gottschall-Pass, 2002, Hinneburg, Dorman \& Hiltunen, 2006).

Given the growing interest and attention on the roles of polyphenols and antioxidants in human health, the presence of these in some spices have formed the subject of a number of publications in the literature (Sikora, Cieslik, Leszczynska, Filipiak-Florkiewicz \& Pisulewski, 2008; Ardestani \& Yazdanparast, 2007). A wide spectrum of spices are grown and consumed in Cameroon but not much information is available on their content of phenolics and their potential as sources of antioxidants. The present study was therefore carried out to bridge this knowledge gap as well as open up new avenues for future research on the relationship between the consumption of these spices and health.

\section{MATERIAL AND METHODS}

Materials: 2,2'-azino-bis (3-ethylbenzothiazoline-6sulphonic acid) diammoniun salt (ABTS), gallic acid, 2-thiobarbituric acid (TBA), rutin were obtained from Sigma Chemical Co. Sodium di-hydrogenate phosphate $\left(\mathrm{NaH}_{2} \mathrm{PO}_{4}\right)$, di-sodium hydrogenate phosphate $\left(\mathrm{Na}_{2} \mathrm{HPO}_{4}\right)$, ethylenediaminetetraacetic acid (EDTA), trichloroacetic acid (TCA), L (+) ascorbic acid, hydrogen peroxide $\left(\mathrm{H}_{2} \mathrm{O}_{2}\right)$, iron chloride $\left(\mathrm{FeCl}_{3}\right)$, potassium di-hydrogenate phosphate $\left(\mathrm{KH}_{2} \mathrm{PO}_{4}\right)$, Ammonium sulfate, Mannitol, and ferric ammonium sulfate were obtained from Prolabo. 6-hydroxy-2,5,7,8-tetramethylchlorman-2carboxylic acid (Trolox), and potassium peroxodisulfalte were obtained from Fluka while sodium hydroxide $(\mathrm{NaOH})$, hydrochloric acid, acetic acid, and sodium acetate from Riedel de Haën Co. Crystalline chloride aluminum $\left(\mathrm{AlCl}_{3}\right)$, and FolinCiocalteu were obtained from Merck. Sodium carbonate was obtained from Labosi, and methanol and ethanol were obtained from Karl Fischer. Acetone was obtained from Carlo Erba, n-butanol from Fischer chemicals, potassium hexacyanoferrate III $\left[\mathrm{K}_{3} \mathrm{Fe}(\mathrm{CN})_{6}\right]$ from Normadur and 2-deoxy-D-ribose from Aldrich.

Spices sampling and processing: Spice sample (table 1) were bought from vendors in a market located in Bafoussam, West province, Cameroon. Each sample was separately cleaned of dirt and dust particles using a forced air current and then sun dried to constant weight before grinding to a powder using a desk top mill (Culatti, Polymix, France) fitted with a $500 \mu \mathrm{m}$ sieve. The ground spices were then put in polyethylene plastic, sealed and stored at $4^{\circ} \mathrm{C}$ in a refrigerator until required for analysis.

Methanolic extracts: Efficiency of extracts is an important factor for the comparison of antioxidant activity. Previous studies reported that relatively higher antioxidant activities were observed from methanolic extracts in grains compared to other solvents including n-hexane, diethyl ether, ethyl acetate, acetone and water (Oki et al., 2002; Sosulski, Krygier, \& Hoogge, 1982; Zielinski \& Kozłowska, 2000). For this reason, methanol was selected as the solvent of choice for extraction in this study. The methanolic extracts were obtained from $20 \mathrm{mg} / \mathrm{ml}$ of ground spice sample. In brief, $250 \mathrm{mg}$ of ground spice sample was extracted by stirring with 25 $\mathrm{ml}$ of methanol at room temperature for 2 hours and filtering through Whatman $\mathrm{N}^{\circ} 1$ (Maidstone, England) filter paper. Residues were re-extracted with additional $25 \mathrm{ml}$ of methanol for a further 2 hours and filtered as described. The volume of the combined extract was removed by evaporation and the lot stored in a sealed tube at $4^{\circ} \mathrm{C}$ until required for use.

Determination of total phenol content: Total phenols content was determined using the FolinCiocalteu colorimetric method as described by Gao, Ohlander, Jeppsson, Björk, and Trajkovski (2000). Plant extracts $(20 \mu \mathrm{l})$ were mixed in a test tube with $0.2 \mathrm{ml}$ of Folin-Ciocalteu reagent and $2 \mathrm{ml}$ of distilled water and incubated at room temperature for $3 \mathrm{~min}$. Following this, $1 \mathrm{ml}$ of $20 \%$ sodium carbonate was added to the mixture, re-incubated for $2 \mathrm{~h}$ at room temperature. The absorbance of the resulting blue color was measured using a quartz cuvet at $765 \mathrm{~nm}$. Gallic acid was used as standard and total phenols were expressed as gram gallic acid equivalents (GAE per $100 \mathrm{~g}$ of dry weight).

Ferric Iron Reducing Activity (FIRA): The antioxidant potential of the different spice extracts was also evaluated by their ability to reduce iron (III) to iron (II) following the method of Oyaizu (1986). In this respect, $1 \mathrm{ml}$ aliquot of each extract, dissolved in distilled water, was mixed with $2.5 \mathrm{ml}$ of phosphate buffer $(0.2 \mathrm{M}, \mathrm{pH} 6.6)$ and $2.5 \mathrm{ml}$ of a $1 \%$ aqueous $\mathrm{K}_{3} \mathrm{Fe}(\mathrm{CN})_{6}$ solution and incubated for 30 minutes at $50^{\circ} \mathrm{C}$. After this, $2.5 \mathrm{ml}$ of $10 \% \mathrm{TCA}$ were added, and the mixture centrifuged for $10 \mathrm{~min} .2 .5 \mathrm{ml}$ aliquot of the supernatant was mixed with $2.5 \mathrm{ml}$ of distilled water and $0.5 \mathrm{ml}$ of $0.1 \%$ aqueous $\mathrm{FeCl}_{3}$, and the 
absorbance at $700 \mathrm{~nm}$ was recorded. Ferric iron reducing activity was determined as ascorbic acid equivalents (mg ascorbic acid/g extract).

Free Radical-Scavenging Activity (FRSA) by the use of a stable ABTS radical cation.: The free radical scavenging activity was determined by ABTS (2,2'-azino-bis (3-ethylbenzothiazoline-6-sulphonic acid)) radical cation decolorization assay described by Re, Proteggente, Pannula, Yang \& Rice-Evans (1999). ABTS radical cation $\left(\right.$ ABTS $\left.^{+}\right)$stock solution $(7$ $\mathrm{mM}$ ) was prepared in a $2.45 \mathrm{mM}$ potassium persulfate solution and kept in the dark at room temperature for $12-16 \mathrm{~h}$ before use. The radical was stable in this form for more than two days when stored at these conditions. For the study, the ABTS ${ }^{+}$ solution was diluted with ethanol to an absorbance $\left(O D_{\text {initial }}\right)$ of $0.700( \pm 0.02)$ at $734 \mathrm{~nm}$ and equilibrated at $30^{\circ} \mathrm{C}$. A reagent blank reading was taken. After addition of $3.0 \mathrm{ml}$ of diluted ABTS ${ }^{+}$solution to $30 \mu \mathrm{l}$ of total phenol extracts, the absorbance reading $\left(O D_{\text {assay }}\right)$ was taken exactly 6 min after initial mixing. The results were corrected for dilution and expressed in $\mathrm{mg}$ trolox per $100 \mathrm{~g}$ dry weight (dw). The percentage of inhibition was calculated using the equation:

$F R S A(\%)=\frac{\mathrm{OD}_{\text {initial }}-\mathrm{OD}_{\text {assay }}}{\mathrm{OD}_{\text {initial }}} \times 100$

Hydroxyl Radical Scavenging Activity (HRSA): The antioxidant activity of extracts was also measured as their ability to inhibit non site-specific hydroxyl radical-mediated peroxidation following the method of Halliwell, Gutteridge, and Aruoma (1987) with some modifications. The reaction mixture use contained $100 \mu \mathrm{l}$ of extract dissolved in distilled water, $500 \mu \mathrm{l}$ of $5.6 \mathrm{mM}$ 2-deoxy-D-ribose in $\mathrm{KH}_{2} \mathrm{PO}_{4}-\mathrm{NaOH}$ buffer (50 mM, pH 7.4), $200 \mu \mathrm{l}$ of premixed $100 \mu \mathrm{M} \mathrm{FeCl}_{3}$ and $104 \mathrm{mM}$ EDTA $(1: 1 \mathrm{v} / \mathrm{v})$ solution, $100 \mu \mathrm{l}$ of $1.0 \mathrm{mM} \mathrm{H}_{2} \mathrm{O}_{2}$ and $100 \mu \mathrm{l}$ of $1.0 \mathrm{mM}$ aqueous ascorbic acid. Tubes were vortexed and incubated at $50^{\circ} \mathrm{C}$ for $30 \mathrm{~min}$. Thereafter, $1 \mathrm{ml}$ of $2.8 \%$ TCA and $1 \mathrm{ml}$ of $1.0 \%$ TBA were added to each tube and the samples vortexed and heated in a water bath at $50^{\circ} \mathrm{C}$ for $30 \mathrm{~min}$. The extent of oxidation was estimated from the absorbance of the solution at 532 $\mathrm{nm}$. The percentage inhibition values were calculated from the absorbance of the control $\left(\mathrm{A}_{\text {control }}\right)$ and of the sample $\left(A_{\text {sample }}\right)$ using equation where the controls contained all the reaction reagents except the extract or positive control substance. The antioxidant activities of the extracts were expressed as mannitol equivalents (mg mannitol/g extract) as followed:

$\operatorname{HRSA}(\%)=\frac{\mathrm{A}_{\text {control }}-\mathrm{A}_{\text {sample }}}{\mathrm{A}_{\text {control }}} \times 100$

Determination of flavonoids: The flavonoids content of the different samples was determined following the method of Mimica-Dukic (1992). Essentially, $1 \mathrm{~g}$ of each ground spice sample was homogenized with $20 \mathrm{ml}$ of extracting solvent (methanol-water-acetic acid, 140:50:10, V/V) and filtered into volumetric flasks and its volume adjusted to $100 \mathrm{ml}$ by addition of extracting solvent. Aliquots of $2.5 \mathrm{ml}$ were transferred into $50 \mathrm{ml}$ volumetric flasks and their volumes made up with water (analyzed solutions). To each $10 \mathrm{ml}$ of analyzed solution, $2 \mathrm{ml}$ of water and $5 \mathrm{ml}$ of $\mathrm{AlCl}_{3}$ reagent (133 mg crystalline aluminum chloride and $400 \mathrm{mg}$ crystalline sodium acetate were dissolved in $100 \mathrm{ml}$ of extracting solvent) were added and absorbance recorded at 430 $\mathrm{nm}$ against a blank made of $10 \mathrm{ml}$ of analyzed solution plus $5 \mathrm{ml}$ of water. The amount of flavonoids was calculated from the calibration curve of rutin standard solutions, and expressed as $\mathrm{mg}$ rutin/100 g of plant material.

Tannins: Tannin levels in the spices were determined by the method of Bainbridge, Tomlins, Wellings, and Westby (1996). Following this method, $1 \mathrm{~g}$ of sample was weighed in a $50 \mathrm{ml}$ volumetric flask followed by the addition $25 \mathrm{ml}$ of $1 \% \mathrm{HCl}$ (in methanol). After $30 \mathrm{~min}$ of agitation, the mixture was centrifuged at $4000 \mathrm{rpm} / \mathrm{min}$ during $10 \mathrm{~min}$ and the supernatant collected and used for the assay of its tannin content. In short, $1 \mathrm{ml}$ of extract was mixed with $5 \mathrm{ml}$ of reactive reagent $(50 \mathrm{~g}$ of vanillin and $4 \mathrm{ml}$ of hydrochloric acid/in $100 \mathrm{ml}$ distilled water) and the mixture incubated at $30^{\circ} \mathrm{C}$ for $20 \mathrm{~min}$ at ambient temperature, and the absorbance read at $500 \mathrm{~nm}$. The amount of tannins was calculated from the calibration curve of tannic acid standard solutions, and expressed as $\mathrm{mg}$ tannic acid $/ 100 \mathrm{~g}$ of plant material.

Statistical analysis: All the chemical analyses were done in triplicate. The results obtained were expressed as means \pm standard deviation and also subjected to one way analysis of variance and Duncan multiple test range when there was a significant $(p<0.05)$ difference using the Statgraphics 3.0 (Manugistics, Rockville, Maryland, USA) statistical software. Principal component 
analysis and K-means classification were performed using the statistical package, StatBox version 6.4 (Grimmer Logiciels, Paris) to group and classify the spices according to their phenols composition and antioxidant potential.

\section{RESULTS AND DISCUSSIONS}

Levels in spices: Generally, the phenolic content of foods is known to have a positive effect on health. The total phenolic content, measured by FolinCiocalteu method, was found to vary significantly $(p<$ 0.001 ) from one spice to another (Table 2). Values obtained varied between 1.05 and $38.80 \mathrm{~g}$ of gallic acid equivalents (GAE)/100 g of dry sample. Fagara leprieuri, and Dichrostachys glomerata with respective mean values of 34.59 and $38.80 \mathrm{~g} / 100 \mathrm{~g}$ were found to contain the highest levels while low levels (ranging between 1.05 and $1.89 \mathrm{~g} \mathrm{GAE} / 100 \mathrm{~g}$ $\mathrm{dw}$ ) were found in Solanum melongena, Hua gabonii (fruit and bark) and Monodora myristica. From a comparative view point, the values found here were higher than those reported for Piper guineense, Piper umbellatum, Scorodophleus zenkeri (seed), and Scorodophleus zenkeri (brak) with respective mean values of $20.94,18.97,18.43$ and $15.12 \mathrm{mg}$ equivalent catechin/g or $990.86,899.10,339.05$, and $480.85 \mathrm{mg}$ equivalent vit E/g (Agbor, Oben, Ngogang, Xinxing, \& Vinson, 2005). In addition very low values (2.8 to $5.8 \mathrm{mg} / \mathrm{g}$ ) were reported for Capsicum species (Howard, Talcott, Brenes and Villaton, 2000). The differences in the phenolic content may be due not only to differences in the analytical techniques used, but also to maturity (Howard et al., 2000). While compared to other foodstuffs analysed with similar method, similar high levels of phenolics have been reported for Bearberry leaves, Arctostaphylos uva-ursi, (31.2 g GAE/100 g) (Amarowicz, Pegg, Rahimi-Moghaddam, Barld \& Weil, 2004), the aerial parts of Horsetail, Equisetum spp. (21.6 g GAE /100 g) (Amarowicz et al., 2004). On the other hand the spices analysed in the present study contain much higher levels of total phenols than those reported by Fulgencio and Isabel (2006) for dry vegetables $(155 \pm 20 \mathrm{mg}$ GAE $/ 100 \mathrm{~g})$, fruits $(538 \pm 20 \mathrm{mg} \mathrm{GAE} / 100 \mathrm{~g})$, cereals $(107 \pm 9 \mathrm{mg} / \mathrm{GAE}$ $100 \mathrm{~g}$ for cereals) or coconut ( $890 \pm 50 \mathrm{mg} \mathrm{GAE} / 100$ g). The levels are equally higher than those (171 to $961 \mathrm{mg} / \mathrm{GAE} 100 \mathrm{~g}$ ) found in some fruits as reported by Richard, Kim, Chad, Balz, and Ronald (2002). The different phenolic levels reported in the literature could partially be associated with the method of extraction. In fact, preliminary work to the present study revealed that extraction yield of phenolics using ethanol was 2 to 3 fold lower than that with methanol.
Flavonoids constitute one of the most important groups of phenolics in plants. In this respect a significant correlation $(r=0.93 ; p<0.05)$ was observed between the flavonoids and the total phenolics content of spices. The spectrophotometric method which was used for the quantification of flavonoids using aluminum chloride has been reported to be specific only for flavones and flavonols, and not for flavanones (Chang, Yang, Wen, \& Chern, 2002). The flavonoids contents of the different spices evaluated varied significantly $(p<$ 0.001 ) from one spice to another with values ranging from $0.00 \mathrm{~g} / 100 \mathrm{~g}$ to $5.94 \mathrm{~g}$ rutin equivalent $/ 100 \mathrm{~g}$ (Table 2). The highest flavonoids levels were found in Dichrostachys glomerata $(5.94 \mathrm{~g} / 100 \mathrm{~g})$ and Fagara leprieuri $(4.46 \mathrm{~g} / 100 \mathrm{~g})$ while the lowest $(0.00 \mathrm{mg}$ $1100 \mathrm{~g}$ to $0.59 \mathrm{~g} / 100 \mathrm{~g}$ ) were found in Capsicum frutescens, Pentadiplandra brazzeana, Hua gabonii (bark), Piper guineense, Solanum melongena, Scorodophleus zenkeri (fruit), scleria striatinux, Piper umbellatum, Fagara xanthoxyloïdes, Hua gabonii (fruit), and Monodora myristica. At the best of our knowledge, literature is very limited on the flavonoids of the spices under study. Those found on Capsicum species reported flavonoids levels between 1.71 and $8.55 \mathrm{mg} / 100 \mathrm{~g}$ fresh sample (Howard et al., 2000) and $166.3 \mathrm{mg} / 100 \mathrm{~g}$ dried weight (Miean and Mohamed, 2001). In addition quercetin and luteolin with respective levels of 39.2 and $103.5 \mathrm{mg} / 100 \mathrm{~g}$ dry weight were identified as the most important flavonoids in Capsicum (Howard et al., 2000; Miean and Mohamed, 2001). For Solanum melongena, Flavonoids were found at a level of $21.95 \mathrm{mg} / 100 \mathrm{~g}$ dry weight with Myricetin (3.9 mg/100g dry weight) and Kaempferol $(8.0 \mathrm{mg} / 100 \mathrm{~g}$ dry sample) being the most important (Miean and Mohamed, 2001). It was equally reported that delphinidin is the main anthocyanin in eggplant with an average level of 7.5 $\mathrm{mg} / 100 \mathrm{~g}$ fresh weight (Koponen et al., 2007). Comparatively to different plants found in literatures, the levels of flavonoids fall within the range observed in the present study: 3.27 to $4.92 \mathrm{~g}$ rutin equivalent $1100 \mathrm{~g}$ for citrus peels (Yuan-Chuen, Yueh-Chueh \& Hsing-Wen, 2008), 0.07 to $1.62 \mathrm{~g}$ catechin equivalents $/ 100 \mathrm{~g}$ for polyphenol-rich Amazonian plant extracts (Souza et al., 2008), 0.21 to $0.49 \mathrm{~g}$ catechin equivalent $/ 100 \mathrm{~g}$ for common herbs in Korea (Kyung, Choong, Hyungjae, BoKyung, \& Chang, 2008); 0.23 - $27.0 \mathrm{mg}$ quercetin equivalents $/ 100 \mathrm{~g}$ for Erica arborea by Mehmet, Fatemeh, Mehmet, Ufuk, and Gülaçti (2007); $0.002 \mathrm{~g}$ to $0.082 \mathrm{~g}$ catechin equivalent/100 $\mathrm{g}$ for various date palm fruits (Foroogh, Abba, \& Azhar, 2008). 
Tannins form a group of phenolics compounds resulting from polymerisation of flavonoids units. The tannin content evaluated by the vanillin assay showed a significant variation $(p<0.001)$ among spices, ranging from 0.00 to $281.5 \mathrm{mg}$ equivalent tannic acid $/ 100 \mathrm{~g}$ dw. Dichrostachys glomerata, Fagara xanthoxyloïdes and Hua gabonii (fruit) presented the highest values while the levels in Solanum melongena, Hua gabonii (bark) and Monodora myristica were below the levels of detection. On the whole the level of tannins in the spices can be considered low when compared to plant materials as some maize hybrids (638 - 2498 mg leucoanthocyanidins/100 g), cowpea seeds (3.35 $\mathrm{g}$ to $12.31 \mathrm{~g}$ catechin equivalents $/ 100 \mathrm{~g}$ ) and horse gram seeds $(0.76 \mathrm{~g}$ tannic acid equivalents $/ 100 \mathrm{~g}$ to $5.80 \mathrm{~g}$ catechin equivalents $/ 100 \mathrm{~g}$ ) reported by Maksimovic, Malencic, and Kavacecic (2005), Perumal and Klaus (2007) and Perumal and Sellamuthu (2007), respectively. From a general perspective, however the levels of tannins in spices were higher when compared to those reported for pecan cultivars $(23-47 \mathrm{mg}$ catechin equivalents/100 g) by José, David, and Jennifer (2007).

Antioxidant activity: Table 2 shows the reducing power (FIRA) of the different spices expressed as ascorbic acid equivalents (mg ascorbic acid/100 $\mathrm{g}$ sample). Generally, the reducing power of the different spices were found to vary significantly $(p<$ 0.001 ) from $1.55 \mathrm{mg} / 100 \mathrm{~g}$ in Capsicum frutescens to $168.63 \mathrm{mg} / 100 \mathrm{~g}$ in Fagara leprieuri. Similar wide variations $(3.8 \mathrm{mg} / 100 \mathrm{~g}$ to $885 \mathrm{mg}$ ascorbic acid/100 g) of reducing power have been reported by Mariko, Hassimotto, Genovese and Lajolo (2005) for dietary fruits, vegetables and commercial frozen fruit pulps. Recent studies in Cameroon (Agbor et al., 2005) had found some herbs and spices to vary in their reducing power from 39.23 to $491.55 \mathrm{mg}$ catechin equivalent/g. For the present study, the spices with highest ferric iron reducing activity were found to be Fagara leprieuri and Dichorstachys glomerata $(128.83 \mathrm{mg} / 100 \mathrm{~g})$. Polyphenolics in these spice extracts appeared to function as good electron and hydrogen-atom donors and therefore serve to terminate radical chain reactions by converting free radicals to more stable products. Of particular interest was the relatively high correlation observed between ferric iron reducing activity power and the total phenolics $(R=0.87)$ or flavonoids $(R=0.79)$, of the samples but very low correlation with tannins $(R=$ 0.29) (table 3). The particularly high correlation observed suggests the contribution of phenolics to the high ferric iron reducing power exhibited by Fagara leprieuri and Dichorstachys glomerata. It is generally believed that the total number of hydroxyl groups present in the aromatic constituents of an extract, in part, offers better antioxidative properties (Miliauskas, Venskutonis, \& Van Beek, 2004). This is however, not always the case since phenolics compounds belongs to different classes which react differently. In the present study, not only a significant correlation existed between the reducing power and the total phenolics in Fagara leprieuri and Dichrostachys glomerata, these two were equally found to have a high antioxidant potential. Particularly we found that Scorodophleus zenkeri (fruit) and Tetrapleura tetraptera which possess similar levels of total phenols exhibited a very wide difference in reducing power, with Tetrapleura tetraptera showing a very high reducing power as opposed to Scorodophleus zenkeri (fruit) which exhibited a very low power. These observations suggest that the reducing power exhibited by different spices is contributed not only by their content of phenolics but also by the presence of other constituents that were not analysed. Thus the antioxidant activity of an extract cannot be predicted only on the basis of its total phenolics content. In fact Kähkönen et al. (1999) found no significant correlation between the total phenolic content and antioxidant activity of 92 plant extracts.

One other important observation made in this study was the highly significant $(R=0.93 ; p<0.05)$ correlation between FIRA of the spices and FRSA (table 3). Recent studies by Saura-Calixto and Goni (2006) had also shown a significant correlation between FIRA and FRSA. Although these results show a close relationship between both methods of evaluating antioxidant capacity, this cannot be generalised since we observed a $3.4 \%$ coefficient of determination when Dichrostachys glomerata and Fagara leprieuri were excluded from the correlation analysis. This suggests that Dichrostachys glomerata and Fagara leprieuri spices extracts were particularly both radical scavengers and powerful reducing agents. While the highest FRSA values were found in Dichrostachys glomerata $(71.50 \mathrm{mg} / \mathrm{g})$ and Fagara leprieuri $(60.07 \mathrm{mg} / \mathrm{g})$, the lowest values were observed in most of the spices (range 3.96 - 6.66 $\mathrm{mg} / \mathrm{g}$ ). In general FRSA determined by the ABTS antioxidant activity expressed as $\mathrm{mg}$ equivalent of trolox per gram of dry sample varied widely (3.96 $\mathrm{mg} / \mathrm{g}$ to $71.50 \mathrm{mg} / \mathrm{g}$ ) in the spices. Average FRSA values were found in Aframomum daniellii (15.39 $\mathrm{mg} / \mathrm{g})$, Xylopia aethiopica (14.41 mg/g), Echinops 
giganteus $(12.54 \mathrm{mg} / \mathrm{g}$ ), and Tetrapleura tetraptera (10.45 mg/g). As in the case of reducing power, FRSA correlated significantly $(R=0.90 ; p<0.05)$ with total phenolics. Saura-Calixto and Goni (2006) also found significant correlation between the FRSA and the total phenolics in plants foods and beverages. This relationship between FRSA and total phenolics has also been reported by many authors (Alonso, Domiänguez, Guilleän, \& Barroso 2002; LuximonRamma, Bahorun, Soobrattee, \& Aruoma, 2002; Landrault et al., 2001; Agbor et al., 2005; Wang, Chuang, \& Ku, 2007). In addition to this, in table 3 , we found a significant between FRSA and the different groups of phenols: flavonoids $(R=0.87$; $p<$ $0.05)$, and tannins $(R=0.46 ; p<0.05)$.

The evaluation of the antioxidant activity of a complex system such as methanol extracts of spices cannot be evaluated using only a one-assay protocol. The two systems reported above measure the total reducing power and the free radical-scavenging activity respectively. In addition we evaluated the protective effect of methanolic extract against deoxyribose attack (HRSA). In the method used, deoxyribose degradation occurs by hydroxyl radicals generated by a Fenton reaction. These methods are widely used to evaluate the antioxidant capacity in foods and biological systems (Keyvan, Damien, Müberra, \& Raimo, 2007). The activities of the extracts were compared to that of mannitol which has been reported to be an effective hydroxyl radical scavenger (Halliwell, Gutteridge, \& Aruoma, 1987). In the site-specific assay, the scavenging radical by different spices changed significantly and the mannitol equivalents ranked from $0.01 \mathrm{~g}$ mannitol/100g extract for Hua gabonii (fruit) and Xylopia aethiopica to $2.45 \mathrm{~g}$ mannitol $/ 100 \mathrm{~g}$ extract for Scorodophleus zenkeri (fruit) (table 2). The richest phenolic extracts, Dichrostachys glomerata exhibited an average activity of $1.52 \mathrm{~g} / 100 \mathrm{~g}$, compared to Fagara leprieuri which exhibited very low activity $(0.07 \mathrm{~g} / 100 \mathrm{~g})$. The different spices equally exhibited low hydroxyl radical scavenging activity when compared to that of others spices and herbs reporting in the literature $(47.5 \mathrm{~mol}$ mannitol $/ \mathrm{g}$ and $387 \mathrm{~mol}$ mannitol/g) (Hinneburg, Dorman \& Hiltunen, 2006).

Multivariate analysis: The Principal Component Analysis (PCA) was applied to the values of phenolics content and antioxidant activities of the different samples analysed. The analysis is based on the correlation between the variables, from which virtual axes linearly correlated to existing variables are generated. The first step in the PCA analysis is the identification of the number of significant axes, called principal components (PC). It is generally believed that principal components with eigen value higher or equal to 1 are significant (Massart, Vandeginste, Deming, Michotte, and Kaufman, 1988). Based on this, 2 principal components were revealed following the execution of PCA of the data obtained as indicated in the correlation circle in figure $1 \mathrm{a}$. In this figure the close proximity of the variables FRSA, FIRA, flavonoids, total phenolics, reveals their inter-correlation. These parameters were highly correlated with the first principal component (PC1, $64 \%$ of total variation between spices) with respective relative weight of $96 \%, 86 \%, 86 \%$ and $91 \%$ (table 4). The second principal component (PC2) according of only $16 \%$ of the total variation among spices was correlated only to Hydroxyl radical scavenging activity (relative weight on PC2 of $96 \%$ ). In the theory of principal component analysis, the PC1 and PC2 axes are perpendicular, suggesting that hydroxyl radical scavenging activities could not be linearly correlated with the variables of the PC2 axis. This was also the case with tannins (relative weight on PC3, $79 \%$ ) which showed a strong correlation with the PC3 axis (14\% of the total variation among spices) (figure $1 \mathrm{~b}$ ).

Figures $2 a$ and $2 b$ show the location of the spices on the PC1 $\times$ PC2 and PC1 $\times$ PC3 plan representing respectively $80 \%$ and $78 \%$ of the contributions to the axis. Table 5 gives the relative contribution of each spice on these different axes. Based on the positions of the spices on mapping, Dichrostachys glomerata and Fagara leprieuri were characterized by positive contribution to PC1 axis; Fagara 1eprieuri, Xylopia aethiopica, Hua gabonii (fruit), Mondia whitei, Piper umbellatum, Pentadiplandra brazzeana and Capsicum frutescens had negative contributions to PC2 and the contributions of Dichrostachys glomerata, Fagara xanthoxyloïdes, Scorodophleus zenkeri (bark), Scorodophleus zenkeri (bark), Piper guineense and to PC2 were positive. Dichrostachys glomerata, Fagara xanthoxyloides and Hua gabonii (fruit) had positive contributions to PC3 while Tetrapleura tetraptera, Hua gabonii (bark) and Scorodophleus zenkeri (fruit) had negative contributions to PC3. On the whole these results suggest that Dichrostachys glomerata and Fagara leprieuri are spices with high FRSA and FIRA, high total phenols and flavonoids content; Scorodophleus zenkeri (bark), Scorodophleus zenkeri (fruit), Piper guineense, Pentadiplandra brazzeana and Monodora myristica are spices with high HRSA; Fagara 
xanthoxyloides and Hua gabonii (fruit) are spices with high tannins contents. Among the spices with high free radical scavenging activity values, Dichrostachys glomerata is characterised by a high HRSA while Fagara leprieuri has a low value of HRSA. This representive classification of the spices was confirmed using K-means classification (table 6) of the spices. Based on this approach the spices were found to fall into four different groups as follows: group 1: Dichrostachys glomerata, Fagara leprieuri; group 2: Fagara xanthoxyloïdes, Mondia whitei, Pentadiplandra brazzeana, Piper guineense, Scorodphleus zenkeri (fruit), Scorodophleus zenkeri (bark); group 3: Aframomum daniellii, Hua gabonii (fruit), Monodora myristica, Dorstenia psilurus, Hua gabonii (bark), Piper umbellatum, Solanum melongena, Scleria striatinux, and Xylopia aethiopica) and group 4: Echinops giganteus, Tetrapleura tetraptera. Group 1 spices were generally those with a high contribution to PC1 while group 2 spices were those with positive contribution to PC2. Group 4 spices had a moderate contribution to PC1 axis, while group 3 was composed of spices with no specific positive contribution on the PC1 and PC2 axes.

\section{CONCLUSION}

The present study revealed large variations in the phenolics and antioxidant activity potential of the spices analysed. Using multivariate analysis, the FIRA, FRSA, total phenolics and flavonoids were linearly correlated to one another. The results of the analysis clearly show that Dichrostachys glomerata and Fagara leprieuri are different from the others as they tend to be relatively very high in their content and potentials of the characteristics analysed. Fagara xanthoxyloïdes, Mondia whitei, Pentadiplandra brazzeana, Piper guineense, Scorodophleus zenkeri (fruit) and Scorodophleus zenkeri (bark) are particularly characterized by a high hydroxyl radical scavenging activity. On the other hand, Dichrostachys glomerata and Fagara leprieuri are of particular interest since these spices are not only rich in phenolics but also possess high antioxidant activity and as such indicate their apparent potential as sources of antioxidants.

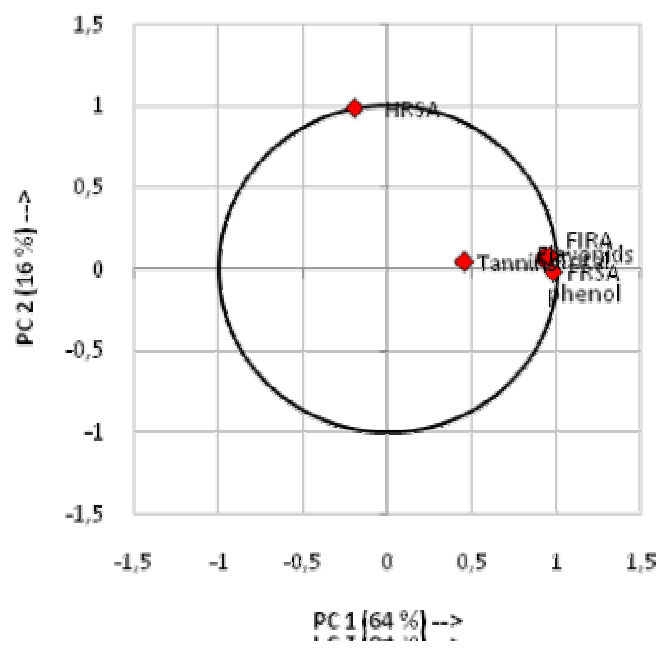

a
PC 1 and PC 3: $78 \%$

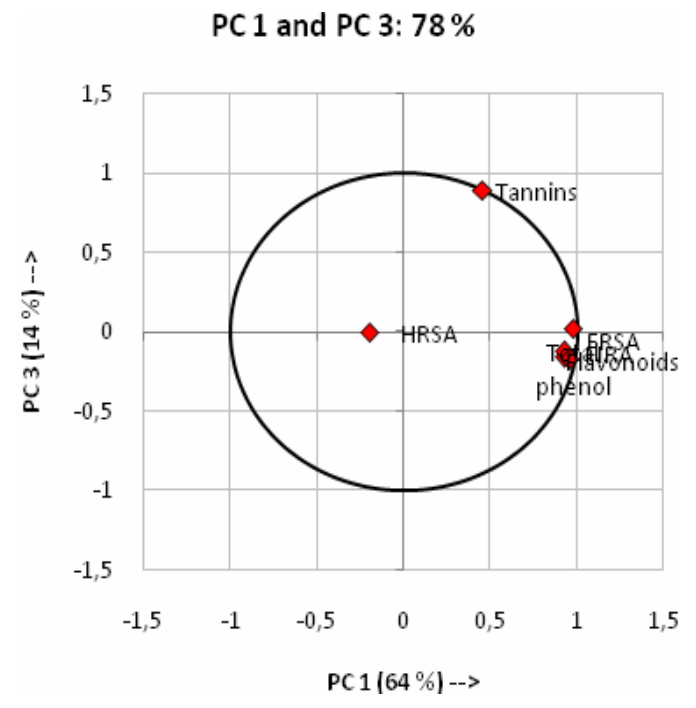

b

Fig 1: Correlation circles of the phenols and antioxidant variables on varimax rotated PC1xPC2 (a) and PC1xPC3 (b) plans. 
PC 1 and PC 2: $80 \%$

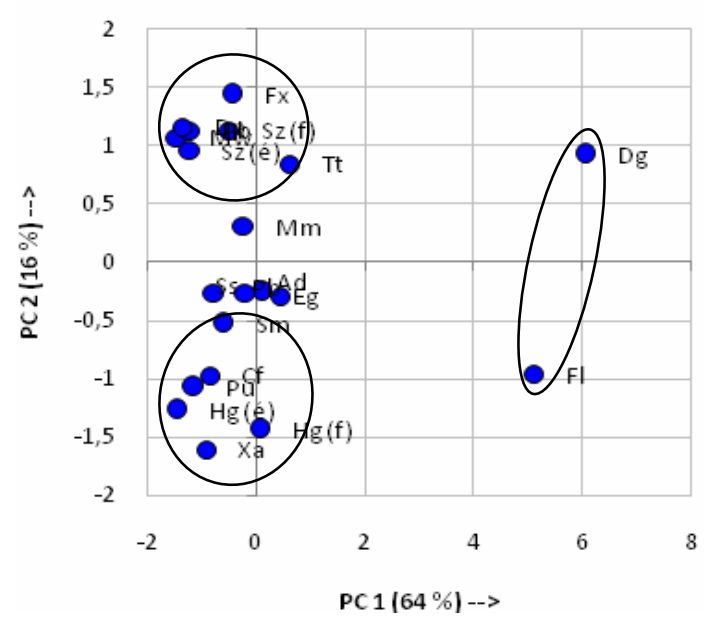

PC 1 and PC $3: 78 \%$

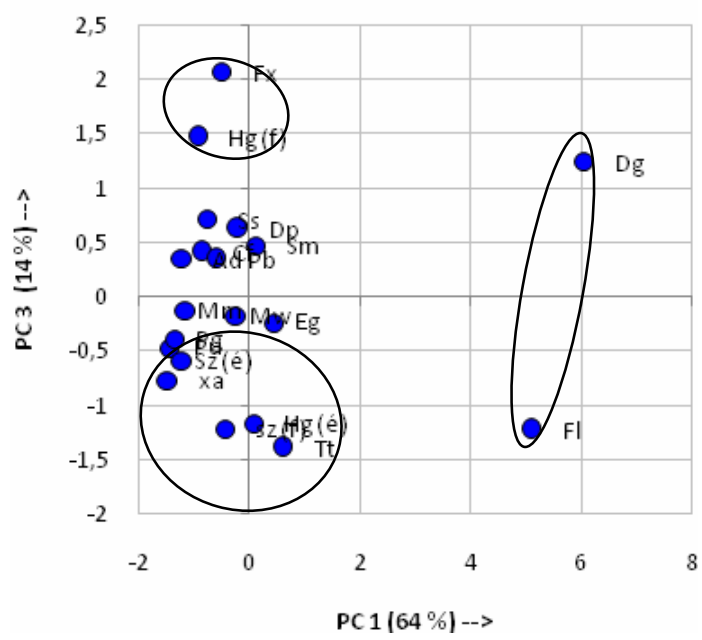

(a)

(b)

Fig 2: Two dimensional plots of spices coordinates on varimax rotated PC1xPC2 (a) and PC1xPC3 (b) axes Refer to table 1 for abbreviation of spices

Table 1: Identification of spices studies

\begin{tabular}{|c|c|c|c|c|}
\hline Botanical name & Common name & General French name & Family & Used parts \\
\hline Aframomum daniellii $(\mathrm{Ad})$ & Bastered melegueta & Maniguette sucrée & Zingiberaceae & Fruit \\
\hline Capsicum frutescens (Cf) & Bird pepper & Petit pigment rouge & Solanaceae & Fruit \\
\hline $\begin{array}{l}\text { Dichrostachys glomerata } \\
(D g)\end{array}$ & Sickle bush & oreilles de souris & Mimosaceae & Fruit \\
\hline Dorstenia psilirus (Dp) & & Remèdes des serpents & Moraceae & Root \\
\hline Echinops giganteus (Eg) & $\begin{array}{l}\text { Giant japanese } \\
\text { butterbur }\end{array}$ & Racines tubéreuse & Asteraceae & Root \\
\hline Fagara leprieuri (FI) & Prickly ash & Grappe odoriférante & Rutaceae & Fruit \\
\hline $\begin{array}{l}\text { Fagara xanthoxyloïdes } \\
(F x)\end{array}$ & & Bouche béante & Rutaceae & Fruit \\
\hline Hua gabonii ( $\mathrm{Hg}(f))$ & Garlic tree & Fruit de l'arbre de l'ail & Huacaceae & Fruit \\
\hline Hua gabonii (Hg (é)) & Garlic tree & Ecorce de l'arbre de l'ail & Huacaceae & Bark \\
\hline Mondia whitei (Mw) & White ginger & Racine sucrée & Periplocaceae & Root \\
\hline Monodora myristica (Mm) & Calabash nutmeg & Fausse noix de muscade & Annonaceae & Almond \\
\hline $\begin{array}{l}\text { Pentadiplandra brazzeana } \\
(P b)\end{array}$ & Joy perfume tree & Liane blanche & Pentadipandraceae & Root \\
\hline Piper guineense $(\mathrm{Pg})$ & Black pepper (Ashandi) & Poivre sauvage & Piperaceae & Fruit \\
\hline Piper umbellatum (Pu) & Cordoncillo & & Piperaceae & Infloraison \\
\hline Scleria striatinux (Ss) & & Racine de chaume & Cyperaceae & Fruit \\
\hline $\begin{array}{l}\text { Scorodophleus zenkeri } \\
(\mathrm{Sz}(f))\end{array}$ & Divida (African) & Fruit de l'arbre à l'ail & Caesalpinaceae & Fruit \\
\hline $\begin{array}{l}\text { Scorodophleus zenkeri } \\
\text { (Sz (é)) }\end{array}$ & Divida (African) & Ecorce de l'arbre à l'ail & Caesalpinaceae & Bark \\
\hline $\begin{array}{l}\text { Solanum melongena } \\
\text { (Sm) }\end{array}$ & Aubergine & Aubergine & Solonaceae & Fruit \\
\hline Tetrapleura tetraptera $(T t)$ & Aidan tree & Fruit à 4 ailes & Mimosaceae & Fruit \\
\hline Xylopia aethiopica (Xa) & $\begin{array}{l}\text { Ethiopian pepper } \\
\text { (African) }\end{array}$ & Poivre d'Éthiopie & Annonaceae & Fruit \\
\hline
\end{tabular}


Agric. Biol. J. N. Am., 2010, 1(3): 213-224

Table 2: Means antioxidant activities and phenolics of the spices

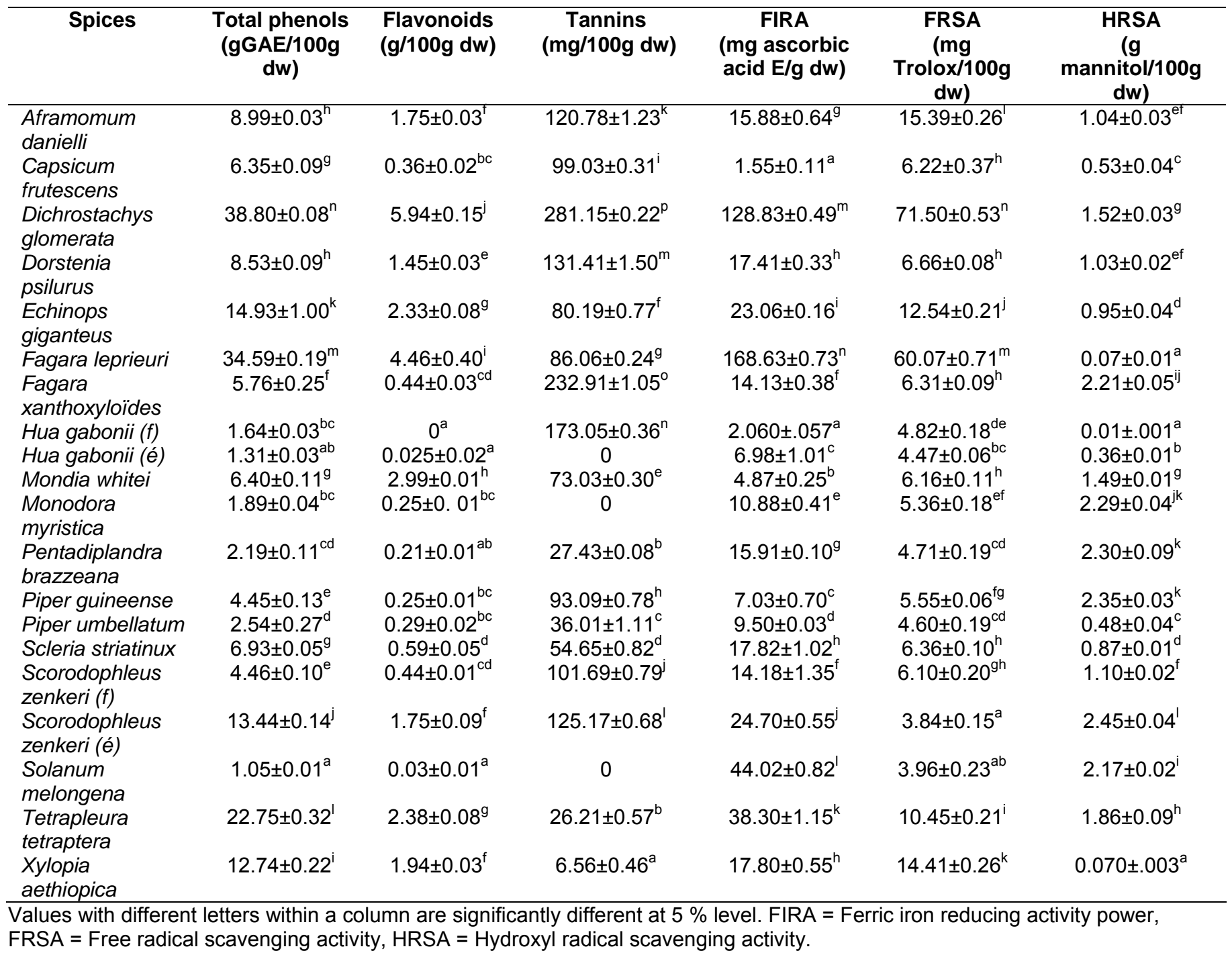

Table 3: Correlation between antioxidant activities and phenolic compounds

\begin{tabular}{lcccccc}
\hline & FRSA & FIRA & HRSA & Flavonoids & Total phenolics & Tannins \\
\hline FRSA & 1 & & & & & \\
FIRA & $\mathbf{0 , 9 3}$ & 1 & & & & \\
HRSA & $-0,21$ & $-0,12$ & 1 & & & \\
Flavonoids & $\mathbf{0 , 8 7}$ & $\mathbf{0 , 7 9}$ & $-0,11$ & 1 & 1 & \\
Total & $\mathbf{0 , 9 0}$ & $\mathbf{0 , 8 7}$ & $-0,12$ & $\mathbf{0 , 9 3}$ & 0,29 & 1 \\
Tannins & $\mathbf{0 , 4 6}$ & 0,28 & $-0,05$ & 0,32 & \\
\hline
\end{tabular}

In bold are significant values at 5\% level. FIRA = Ferric iron reducing activity power, FRSA = Free radical scavenging activity, HRSA = Hydroxyl radical scavenging activity 
Agric. Biol. J. N. Am., 2010, 1(3): 213-224

Table 4: Loading contribution (\%) of parameters analyzed to the PC axes

\begin{tabular}{lccc}
\hline & PC 1 & PC 2 & PC 3 \\
\hline FRSA & 0,96 & 0,00 & 0,00 \\
FIRA & 0,86 & 0,00 & 0,03 \\
HRSA & 0,04 & 0,96 & 0,00 \\
Flavonoids & 0,86 & 0,01 & 0,02 \\
Total phenolics & 0,91 & 0,01 & 0,03 \\
Tannins & 0,21 & 0,00 & 0,79 \\
\hline
\end{tabular}

FIRA = Ferric iron reducing activity power, FRSA $=$ Free radical scavenging activity,

HRSA $=$ Hydroxyl radical scavenging activity, $\mathrm{PC}=$ principal component

Table 5: Loading contribution (\%) of spices to the PC axes

\begin{tabular}{|c|c|c|c|}
\hline & PC 1 & PC 2 & PC 3 \\
\hline Aframomum daniellii & 0,03 & 0,14 & 0,50 \\
\hline Capsicum frutescens & 0,38 & 0,49 & 0,09 \\
\hline Dichrostachys glomerata & 0,93 & 0,02 & 0,04 \\
\hline Dorstenia psilurus & 0,06 & 0,11 & 0,60 \\
\hline Echinops giganteus & 0,27 & 0,11 & 0,07 \\
\hline Fagara leprieuri & 0,88 & 0,03 & 0,05 \\
\hline Fagara xanthoxylum & 0,04 & 0,22 & 0,72 \\
\hline Hua gabonii (f) & 0,15 & 0,46 & 0,38 \\
\hline Hua gabonii (é) & 0,48 & 0,36 & 0,13 \\
\hline Monodora myristica & 0,03 & 0,05 & 0,02 \\
\hline Mondia whitei & 0,57 & 0,31 & 0,06 \\
\hline Pentadiplandra brazzeana & 0,48 & 0,42 & 0,04 \\
\hline Piper guineense & 0,53 & 0,39 & 0,04 \\
\hline Piper umbellatum & 0,52 & 0,46 & 0,01 \\
\hline Solanum melongena & 0,45 & 0,35 & 0,15 \\
\hline Scleria striatinux & 0,49 & 0,06 & 0,42 \\
\hline Scorodophleus zenkeri (f) & 0,05 & 0,53 & 0,38 \\
\hline Scorodophleus zenkeri (é) & 0,39 & 0,24 & 0,09 \\
\hline Tetrapleura tetraptera & 0,10 & 0,19 & 0,53 \\
\hline Xylopia aethiopica & 0,00 & 0,56 & 0,37 \\
\hline
\end{tabular}

Table 6: K-means classification of the spices

\begin{tabular}{|c|c|c|c|}
\hline $\begin{array}{c}\text { Class } 1 \\
\text { (High FRSA, FIRA, } \\
\text { phenols, Flavonoids,) }\end{array}$ & $\begin{array}{c}\text { Class } 2 \\
\text { (High HRSA) }\end{array}$ & $\begin{array}{l}\text { Class } 3 \\
\text { Lower levels for all the } \\
\text { variables }\end{array}$ & $\begin{array}{c}\text { Class } 4 \\
\text { Moderate FRSA, } \\
\text { FIRA, phenols, } \\
\text { Flavonoids, }\end{array}$ \\
\hline Dichrostachys glomerata & Fagara xanthoxyloïdes & Aframomum daniellii & Echinops giganteus \\
\hline \multirow[t]{9}{*}{ Fagara leprieuri } & Mondia whitei & Capsicum frutescens & Tetrapleura tetraptera \\
\hline & Pentadiplandra brazzeana & Dorstenia psilurus & \\
\hline & Piper guineense & Hua gabonii (f) & \\
\hline & Scorodophleus zenkeri (f) & Hua gabonii (é) & \\
\hline & Scorodophleus zenkeri (é) & Monodora myristica & \\
\hline & & Piper umbellatum & \\
\hline & & Solanum melongena & \\
\hline & & Scleria striatinux & \\
\hline & & Xylopia aethiopica & \\
\hline
\end{tabular}


ACKNOWLEDGEMENTS: The authors are grateful for the financial assistance form International Foundation for Sciences (IFS, Stockholm, Sweden. We also thank the Cooperation Française which, through a scholarship award to Abdou Bouba, facilitate the carrying out of the study in INPL, NancyUniversité, France

\section{REFERENCES}

Agbor, G. A., Oben, J. E., Ngogang, J. Y., Xinxing, C. \& Vinson, J. A. (2005). Antioxidant Capacity of Some Herbs/Spices from Cameroon: A comparative study of two methods. J Agric Food Chem, 53, 6819-6824.

Alonso, A. M., Domiänguez, C., Guilleän, D. A., \& Barroso, C. G. (2002). Determination of Antioxidant Power of Red and White Wines by a New Electrochemical Method and Its Correlation with Polyphenolic Content. J Agric Food Chem. 50, 3112-3115

Amarowicz, R., Pegg, R.B., Rahimi-Moghaddam, P., Barld B., \& Weil J. A. (2004). Free-radical scavenging capacity and antioxidant activity of selected plant species from the Canadian prairies. Food Chem, 84, 551-562.

Ardestani, A. \& Yazdanparast, R. (2007). Antioxidant and free radical scavenging potential of Achillea santolina extracts. Food Chem, 104, 21-29.

Bainbridge, Z., Tomlins, K., Wellings, K., and Westby, A. (1996). Methods for assessing quality characteristics of non-grains starch (Part 3. Laboratory methods). Chathom, UK: Natural Resources Institute.

Chang, C. C., Yang, M. H., Wen, H. M., and Chern, J. C. (2002). Estimation of total flavonoid content in propolis by two complementary colorimetric methods. J Food and Drug Analysis, 10, 178-182.

Foroogh, B., Abba. F.M.A. and Azhar M.E. (2008). Antioxidaant activity and phenolic content of various date palm (phoenix dactylifera) fruits from Iran. Food Chem, 107, 1638-1641.

Gao, X., Ohlander, M., Jeppsson, N., Björk, L. and Trajkovski, V. (2000). Changes in antioxidant effects and their relationship to phytonutrients in fruits of sea buckthorn (Hippophae rhamnoides L.) during maturation. J Agric Food Chem. 48, 1485-1490.

Halliwell, B. (1996). Antioxidants in human health and disease. Annual Reviews in Nutrition, 16, 33-49.

Halliwell, B., Gutteridge, J. M.C., and Aruoma, O. (1987). The deoxyribose method: a simple "test tube" assay for determination of rate constants for reactions of hydroxyl radicals. Analytical Biochem, 165, 215-219.

Hinneburg, I.. Dorman, H. J. D. and Hiltunen R. (2006). Antioxidant activities of extracts from selected culinary herbs and spices. Food Chem. 97:122-129.

Howard R.L., Talcott T.S., Brenes H.C. and Villaton B. 2000. Changes in Phytochemical and antioxidant activity in different pepper cultivars (Capsoicum species) as influenced by maturity. J Agric Food Chem. 48:1713-1720.

José, Ä. G., David, S. L., and Jennifer, M. A. (2007). In Vitro Antioxidant Activity of Coffee Compounds and Their Metabolites. J Agric Food Chem. 55:6962-6969

Kähkönen, M. P., Hopia, A. I., Vuorela, H. J., Rauha, J.-P., Pihlaja, K., and Kujala, T. S. (1999). Antioxidant activity of plant extracts containing phenolic compounds. J Agric Food Chem. 47:3954-3962.

Keyvan, D. H. J., Damien, D., Müberra, K., and Raimo, H. (2007). Chemical composition and in vitro antioxidant evaluation of a water soluble Moldavian balm (Dracocephalum moldavica L.) extract. LWT - Food Sci Technol, 40, 239-248.

Koponen M.J., Happonen M.A., Mattila H.P. and Torranen. 2007. Contents of anthocyanins and ellagitannins in selected foods consumed in finland. J Agric Food Chem. 55:1612-1619.

Kyung, M.Y., Choong, H. L., Hyungjae, L., BoKyung, M., and Chang, Y. L. (2008). Relative antioxidant and cytoprotective activities of common herbs. Food Chem. 106, 929-936

Landrault, N., Poucheret, P. Ravel, P, Gasc, F., Cros, G. and Teissedre, P.-L. (2001). Antioxidant capacities and phenolics levels of french wines from different varieties and vintages. J Agric Food Chem. 49, 3341-3348

Liu, F., and Ng, T. B. (2000). Antioxidative and free radical scavenging activities of selected medicinal herbs. Life Science, 66(8), 725-735.

Luximon-Ramma, A., Bahorun, T., Soobrattee, M. A., and Aruoma, A. I. (2002). Antioxidant Activities of Phenolic, Proanthocyanidin, and Flavonoid Components in Extracts of Cassia fistula. J Agric Food Chem, 50: 5042-5047

Maksimovic, Z., Malencic D., and Kovacevic N. (2005). Polyphenol contents and antioxidant activity of Maydis stigma extracts. Bioresource Technol. 96: 873-877

Mariko, N., Hassimotto, A. Genovese, M. I., and Lajolo, F. M. (2005). Antioxidant activity of dietary fruits, vegetables, and commercial frozen fruit pulps. J Agric Food Chem. 53, 2928-2935.

Massart, D. L., Vandeginste, B. G. M., Deming, S. N., Michotte, Y., and Kaufman, L. (1988). Principal components and factor analysis. Chemometrics: A textbook. Amsterdam: Elsevier, pp. 339-369.

Mehmet, A., Fatemeh, B., Mehmet, Ö., Ufuk, K. and Gülaçti, T. (2007). Antioxidant activity of Erica arborea. Fitoterapia, 78, 571-573.

Miean H.K. and Mohamed S. 2001. Flavonoid (Myricetin, Quercetin, Kaempferol, luteolin and apigenin) content of edible tropical plants. J Agric Food Chem. 49, 31063112

Miliauskas, G., Venskutonis, P. R., and Van Beek, T. A. (2004). Screening of radical scavenging activity of 
some medicinal and aromatic plant extracts. Food Chem. 85, 231-237.

Mimica-Dukic, N. (1992). Investigation on secondary biomolecules in some Mentha-species. Ph.D. Thesis. University of Novi Sad.

Morrissey, P.A., and O'Brien, N. M. (1998). Dietary antioxidants in health and disease. Int Dairy J. 8, 463472.

Muramatsu, H., Kogawa, K., Tanaka, M., Okumura, K., Koike, K., Kuga, T., et al. (1995). Superoxide dismutase in SAS human tongue carcinoma cell line is a factor defining invasiveness and cell motility. Cancer Res, 55, 6210-6214.

Oki, T., Masuda, M., Kobayashi, M., Nishiba, Y., Furuta, S. and Suda, I., (2002). Polymeric procyanidins as radical-scavenging caomponents in red-hullled rice. $\mathrm{J}$ Agric Food Chem., 50, 7524-7529.

Oyaizu, M. (1986). Studies on products of browning reaction: antioxidative activity of products of browning reaction. Japanese J Nutr, 40, 307-315.

Perumal, S. and Klaus, B. (2007). The antioxidant and free radical scavenging activities of processed cowpea (Vigna unguiculata (L.) Walp.) seed extracts. Food Chem., 10, 10-19.

Perumal, S. and Sellamuthu, M. (2007). The antioxidant activity and free radical-scavenging capacity of dietary phenolic extracts from horse gram (Macrotyloma uni.orum (Lam.) Verdc.) seeds. Food Chem., 105, 950-958

Pokorny, J. (1987). Major factors affecting the autoxidation in lipids. In: CHAN, H. (Ed.), Autoxidation of Unsaturated Lipids. London: Academic Press, pp. 141206.

Re, R. N. P., Proteggente, A., Pannula, A., Yang, M. and Rice-Evans C. (1987). Antioxidant activity applying an improved ABTS radical cation decolorization assay. Free Radical Biology and Medecine, 26:1231-1237.

Rice-Evans, C., Miller, N., and Paganga, G. (1996). Structure-antioxidant activity relationships of flavonoids and phenolic acids. Free Radical Biology and Medicine, 20, 933-956.

Richard, A. M., Kim, E. H., Chad E. F., Balz, F. and Ronald E. W. (2002). Anthocyanins, Phenolics, and Antioxidant Capacity in Diverse Small Fruits: Vaccinium, Rubus, and Ribes. J Agric Food Chem., $50,519-525$

Saura-Calixto, F. and Goni, I. (2006). Antioxidant capacity of the Spanish Mediterranean diet. Food Chem., 94, 442-447

Sikora, E., Cieslik, E., Leszczynska, T., Filipiak-Florkiewicz, A. and Pisulewski, P. M. (2008). The antioxidant activity of selected cruciferous vegetables subjected to aquathermal processing. Food Chem. 107, 55-59

Soobrattee, M. A., Bahorun, T., Neergheen, V. S., Googoolye, K., and Aruoma, O. I. (2007). Assessment of the content of phenolics and antioxidant actions of the Rubiaceae, Ebenaceae, Celastraceae, Erythroxylaceae and Sterculaceae families of Mauritian endemic plants. Toxicology in Vitro, In press.

Sosulski, F., Krygier, K., and Hogge, L. (1982). Free, esterified, and insoluble-bound phenolic acids. 3. Composition of phenolic acids in cereal and potato flours. J Agric Food Chem., 30, 337-340.

Souza, J. N. S., Silva, E. M, Loir, A., Rees, J.-F., Rogez, H. and Larondelle, Y. (2008). Antioxidant capacity of four polyphenol-rich Amazonian plant extracts: A correlation study using chemical and biological in vitro assays. Food Chem., 106, 331-339.

Statgraphics. (1997). Statgraphics plus for windows 3.0. Rockville, MD: Manugistics Inc.

Statsoft. (2001). Statistica (data analysis Software system) version 6.

Steinberg, D.; Parthasarathy, S.; Carew, T. E.; Khoo, J. C.; Witztum, J. L. (1989). Beyond cholesterol. Modifications of low density lipoprotein that increase its atherogenicity. N. Engl. J. Med, 320, 915-924.

Stoilova, I., Krastanov, A., Stoyanova, A., Denev, P., and Gargova, S. (2007). Antioxidant activity of a ginger extracts (Zingiber o.cinale). Food Chem., 102, 764770.

Sweeney, M. I., Kalt, W., Mackinnon, S. L., Ashby, J., and Gottschall- Pass, K. T. (2002). Feeding rats diets enriched in lowbush blueberries for six weeks decreases ischemia-induced brain damage. Nutritional Neuroscience, 5(6), 427-431.

Velioglu, Y. S., Mazza, G., Gao, L., and Oomah, B. P. (1998). Antioxidant activity and total polyphenolics in selected fruits, vegetables, and grain products. J Agric Food Chem., 46, 4113-4117.

Wang, Y. C., Chuang, Y. C., and Ku, Y. H. (2007). Quantitation of bioactive compounds in citrus fruits cultivated in Taiwan. Food Chem., 102, 1163-1171.

Yuan-Chuen, W., Yueh-Chueh, C. and Hsing-Wen, $\mathrm{H}$. (2008). The flavonoids, carotenoids and pectin content in peels of citrus cultivated in Taiwan. Food Chem., 106, 277-284.

Zheng, W., and Wang, S. (2001). Antioxidant activity and phenolic composition in selected herbs. J Agric Food Chem., 49, 5165-5170.

Zielinski, H., and Kozłowska, H. (2000). Antioxidant activity and total phenolics in selected cereal grains and their different morphological fractions. J Agric Food Chem., 48: 2008-2016. 